\title{
12 THESES FOR UNDERSTANDING THE ETHICS OF ST. CLEMENT OF OHRID
}

\author{
Abstract \\ Culture and its range depend on the ethics of the people who create it. The con- \\ clusion is based on the experience in the creation of a culture in an area that gave the pe- \\ ople in part of Europe literacy and new ways of understanding the world. Such was the eth- \\ ics of St. Clement of Ohrid... \\ By giving us the letters, God commits us to doing good, and not evil. Realizing this, \\ St. Clement did not find it difficult to move a step forward towards the bare acceptance of \\ the ethical postulates by saying: It is not enough to simply run away from the evil, but one \\ should also do good! This led to the creation of a code of conduct that is: \\ - Ethics that offers knowledge; \\ - Knowledge of God within oneself, for oneself; \\ of others; \\ - Ethics of creating personal identity and recognizing and respecting the identities \\ The lack of such interdisciplinary thinking about this type of role of ethics in these \\ areas, as well as its consequences, represent open opportunities for a global clash of the cul- \\ tures.
}

Key words: ETHICS, EVIL, GOD, EDUCATION

\section{Introduction}

In order to really understand what and who St. Clement of Ohrid is and what his role and the role of his ethics is in the foundation of the understanding of the universality of the ethical values and the axiological system of the same, we must start from the thesis that culture and its scope depend on the ethics of the people who create it. The conclusion is based on the experience in creating a culture in the area where we live and which in most of Europe, helped share literacy, and offered an ethics regarding the ways of understanding the world.

An example of a concrete realization of such an ethics is the ethics of acting of St. Clement of Ohrid, for whom the possibility to perceive the world as a manifestation of God is a key postulate! Namely, the function of ethics and the ethical in the acting in order to belong to God is more than an apostrophe in his writings, i.e. in all his texts, in which the essence of his existence and action can be recognized on every page. 
Although the former may sound too general, it accurately determines the value system of ethics from which and for which St. Clement acts. Namely, Saint Clement, by offering a cognizance of God and his perception, points out that it is not enough to only know, but the perceived and the realized should also be used and by proclaiming: "Guard yourself from evil and do good!" (Охридски, 1996; 110) - he actually demands responsibility from each of us for everyone, both before ourselves and before God. He demands responsibility not in the sense that we must persuade others to doforce them to do what we do, the way we do it, to think what we think, to believe in the same God in the same way we do... but in the sense that the spreading of the field of knowledge and cognition opens up the opportunity for each of us to find God in ourselves, for God, but also for what should be done so that the world is in harmony with God's purpose for it.

\section{Through education to understanding of the world}

Specifically summed up through several theses, when speaking about and rethinking Saint Clement's ethics, the following 12 theses should be emphasized:

1. By deciding to dedicate his life to God and to act in his name, St. Clement goes further by practicing the commandment: "You shall love your neighbour as yourself!", and by opening the Ohrid University where not only God's word is studied, but a series of practical sciences as well. With that, he lays down the foundations of social evolution as the basis of social change that will eventually lead to a society of equal participants in its creation. In order to finally clarify this ethical-sociological and social aspect of his action, here I would mention only that St. Clement, in the light of the historical, social and political circumstances, was not able to start a revolution, but realizing that we are all equal before God, he thought that we should all be equal in society as well, and this can only be achieved if we have equal opportunities for knowledge and cognition, as preconditions for a better and more ethical quality of life.

In order for the previous to be clearer, consequently derived, it means that by raising the level of practical knowledge and cognition, a part of the society evolves, which can, by multiplying, increase the number of those who will create conditions that will lead to social changes in the sense of equality of all human beings. In this context, as emphasized by prof. Kiril Temkov, "What amazes us is his concern for the duty he performed for the believers who had been entrusted to him, for the city of Ohrid upon which he tried to establish God's blessing ${ }^{1}$ for the people who expected word, advice, and instructions from him" (Темков, 2006);

${ }^{1}$ And that he succeeded in it tells us the fact that the citizens of the city of Ohrid and the Ohrid Archbishopric, today known as the Macedonian autocephalous Orthodox Church, the same one 
2. For this purpose, he founded an Orthodox Slavic People's Church through which he expanded education and culture, not only in Macedonia, but also in the countries of the other Slavs. But, the thing that is for admiration and that proves the ethical justification of the actions of St. Clement of Ohrid and his loyalty and God's message and the gift of God given to everyone, regardless of linguistic or other affiliation, is that he did so by not infringing neither the identity nor the sovereignty of the church to which one belongs and of the people to whom God's word is offered. Risking to come to a clash with the official view that INRI and the one who is crucified under him can be interpreted in only three languages, St. Clement of Ohrid, realizing that the human heart and the opening of it to God can be reached by speaking his language and from his world, he correctly decides to forget about the three language dictionaries, deciding properly (which history of the spreading of God's word among the Slavic peoples has proved) to preach the truth about the Father, the Son and the Spirit, and teach the people in his language. After all, he did not need official approval because it is known that Christ commanded the Gospel to be preached to all nations, and to fulfil this, the Holy Spirit, on the fiftieth day, came down and gave power to the apostles to preach by using the language of the people which should bring him to the gates of the Kingdom of Heaven.

3. Starting from such an understanding of the Gospel, St. Clement practically shows and proves that he had understood Christ the Saviour and God as they are shown to us, i.e. as Christ the Saviour and God from God for all. But, most importantly, he understood from God's words not only that the nations and their differences should not be denounced, but that there are "no privileged" (Митревски, 66-67) who will rule over others. It shows that his ethics is based on God's understanding of diversity. He realized that God created them not out of entertainment, but from the need to unite in the differences, to discern the diversity of the world and God's appearance. But, more importantly, it is God's purpose by uniting in those differences to be able to demonstrate its wholeness, or by uniting in the differences, to be able to show the universality of the claim that there is ethics in each of us ever since birth. This would come not only to what is called "globalization" in modern times, but more importantly, for then and for now - to the unity in God (no matter what it is called), in love and justice and righteousness for everyone, not just as a Christian duty, but as

from which the churches later asked for a consent in order to be established, proclaimed him for the patron saint of their city - (D.D. Mar. Auth.) 
a duty of every man to everyone, to God in oneself, to oneself and from oneself. ${ }^{2}$

4. From today's context, such ethics could essentially mean advocating the right of everyone to free choice, how one will live, which in fact means that the foundation of this ethic is not just understanding of oneself as a temple of God, but accepting everyone as such. This consequently leads to a willingness to have a dialogue, a mutual understanding of everyone with everyone. But, not a dialogue based on a bare argument of the type "it exists - it does not", or "it is good - bad", but a dialogue that leads to the discovery of the need-knowledge-the way of one's own cognition and understanding of the argument of the one next to/against us.

5. Being aware of the fact that knowledge in any form remains only an opportunity if the ways of its expansion are not multiplied and consistent with the thesis of consciousness that cognition is universal property, which speaks of the ethics for which and in the name of which he acts, St. Clement as a good didactitian and methodologist, having the purpose of the knowledge of God and the world to be accessible to everyone, revises the offered letters in order to come to real literacy. Namely, he revises the Glagolitic script, moulds it graphically, in accordance with the mentalethical assembly of nations to which it has to serve as a means of communication, not with God, but to know God within themselves. This approach to the graphic expression of the thought of God and to God intuitively perceives that every sign can be accepted as information and can only grow if it is exemplary and measured on the basis of the user's spatialmental habitual, and it likewise means that he sees literacy as a path to the truth.

6. The fact that St. Clement recognizes the literacy as a path to the truth, is confirmed by the already mentioned Theophylact, who states: "We never saw him not working, he was either teaching children, or it was diverse: Showing some of the letters to some, explaining the meaning of the written to others, and directed the hands of the third for writing, not only by day, but by night as well; giving himself over to a prayer or working on reading or writing books". From this Theophylact's statement about the teaching activity of St. Clement of Ohrid one more thing can be concluded when it comes to this founder, who is not founder of the Macedonian literacy and ethics only. Namely, if his specific activities are analyzed, it is quite clear that the expression "the child of God" has been understood in

\footnotetext{
${ }^{2}$ St. Clement with his life and work showed the same and proved that the only way to be of service to God is shown not only by the authors who wrote about him, but also by the fact that his cult is well-nourished in many Slavic countries in the present day.
} 
the sense that one cannot come to God with God, from himself, to God, if attention is not paid to one's cultivation from the very first breath of life.

7. This remark also applies to another view of St. Clement and the ethics he has advocated. Namely, this text would not be if there was no behaviour, i.e. consciousness among those who create children that by making them literate, they enable them not only to receive the word of God, but also to know in themselves and to subdue themselves so that they can be part of others, thus reaching beyond their parents, more precisely, to what we are today: people who, fortunately, are increasingly asking themselves why would they need this word if they do not use it to recognize God in themselves and in the other and in communion with those others to reach Him. More precisely, what is the use of our word-knowledge if, through our own reading, we do not reach the knowledge of ourselves as existence should be subordinate to creating such relations in the world (and in the production of the economy) that will lead us to the reason why we are present on this planet: to the type of (bio)ethical behaviour and acting because we are aware that only through respecting the bestowed can one's own existence for oneself and for the others be justified.

8. Regardless of which profession we will choose, St. Clement's conduct is a roadmap and proof that it is not only for us, to present ourselves as chosen by God in order to teach others, but to enable others to perceive the learned and to transmit it as knowledge to others. The correctness of this was demonstrated by St. Clement's concrete activity in the spreading of education that was not limited to only teaching to read letters, but also endeavoured to convey it to the clergy and clerics ${ }^{3}$ aware that the "alb" they carry is another argument plus to make ignorant people literate, not only to be able to read God's Word, but to read the signs in the world and the nature that will enable one not to be afraid of it and worship it in the pagan way, but to possess it as part of oneself, given by God, to return to God protecting both the (bio) mass and the (bio) potential of it. ${ }^{4}$

\footnotetext{
${ }^{3}$ St. Clement's statement is also in this sense: "The bishop and the priest deserve to teach and direct the people entrusted to them. And they themselves are the first ones to be distracted by all evil ... Because it is said that the bishop should be without sins, as a divine messenger, that he would not please himself, nor be angry, drunk and evil, greedy for gifts, but he would be hospitable and righteous, help those entrusted to him, teach them with words. He would be a powerful comforter, in a healthy science, he would reprove the opponents of the faith, give an example for everything with a good deed" (Климент Охридски, Похвали и йоуки, 156).

${ }^{4}$ In the context of this, speaking of literacy as a way of cognition, not by chance is St. Clement mentioned as the first acquaintance of the knowledge of the Macedonian Slavs. Here, it is insisted on the word "acquaintance", and not "teacher", because the word "acquaintance" indicates that I do not teach you to repeat, but that by acquainting you, you learn to think and appreciate the acquainted" (Митревски, 22-31).
} 
9. When it comes to what has St. Clement made to date in relation to all of the above, and by taking into account the next attitude, and even then and today, we can talk about the fact that through his actions and ethics from which he was motivated, he offered to solve another ethical problem even then and today: namely, with his action and the result of it, he leads to the realization that there is no unity neither in God, nor for God, neither in society nor for society, without respecting the individual sovereignty and identity of every creature of God. This is exactly the universality of Saint Clement's ethics, because the knowledge of God and his cognizance as a consciousness of one environment translates to the language of the other, allowing oneself to feel in that environment as part of the All-God, but at the same time respecting one's own cultural heritage, to recognize oneself as a set of personal entities and identities, but not less, and as a set of sovereigns, renouncing part of one's own sovereignty, which may be put into the service of the other in order to meet one's own role as God's creation to do good to the other - because doing good to the other is necessary because the goodness is God given for him to be given to another!

10. This attitude toward literacy and becoming literate, i.e. perceived as a path to the truth, leads St. Clement to another fact, which is that he learned that: in order to come to God, it is not enough just to read the Bible, to interpret it according to the current needs of those who determine the rules of playing, but certain other knowledge and cognition of the human nature is also necessary, and therefore he opens the University in which one of the basic subjects for studying is the study of human health and the ways of its preservation ${ }^{6}$ from where the ancient rule arises: "A healthy mind in a healthy body." This is done not only because he is idolatrous toward such a philosophy, but because he is ethically conscious to the extent that he accepts "pagan philosophy", he points to and proves the

\footnotetext{
${ }^{5}$ Starting from this, not only by declaring but also by specifically engaging, he organizes what today, regardless of the attempts to erase history, is called the first University at which in addition to the word of God, it is also taught what is ours given from God - it is learned how to preserve the legacy.

${ }^{6}$ All benchmark libraries of the Slavic cultural and philosophical heritage (among which one of the wealthiest is the Moscow archive) confirm that St. Clement of Ohrid is true to the word of God, i.e. that we can only serve healthy, write texts with medical indications on how to maintain a healthy body so that the spirit would be healthy for God in ourselves, for God in others. This is also confirmed by the following texts: "The word of St. Doctors Kuzman and Damjan", "Law of Faithful Journey", and "Anthropology". These are the works in which St. Clement of Ohrid gives specific instructions both for the married life and for its purity, and he gives an indication, speaking about the necessity of maintaining the purity and the premises in which one lives, the way one thinks, lives and with that to justify ourselves as beings who today aspire to what everyone is discussing - (bio) ethically guided and determined beings.
} 
fact that there is no philosophy or a religion that does not have universal ethical values in itself. The question is just how much we are willing to discover them as such and make our own way of life with which we would perceive ourselves as God's act of creation - beings for creating goodness as evidence of the reality of God.

11. At the end, this thesis means that St. Clement's ethics is the ethics of proving God's eternalness and his omnipotence only when his temple man, serves not the temple, but the All-creator. This again points to and shows another aspect of St. Clement's ethics. Namely, by having a healthy body, and thus having a healthy spirit, we can also treat well ourselves and others. More precisely, this means that when we decide to reproduce, we will be able to think about what we will reproduce, how we will reproduce and in the name of what we will reproduce. This reflection on St. Clement's ethical lesson suggests that he had taken over some of the (bio)ethical views of the Old Testament.

12. This valorisation of St. Clement's ethics is not because St. Clement is the initiator of a culture and identity - the Macedonian, but because only through such ethics, such behaviour and understanding of the function of God in man and of man for God, by offering knowledge and through cognition, every people - nation can come to itself as such, to build identity through its own foundations, and become clear why and how it has been realized in these regions where tolerance is part of the mental structure, and the feeling of belonging, despite indisputable violent impacts, remained part of the reason for the survival of the nations. In other words, speaking of St. Clement's ethics, it is clear that this is an ethics according to which the understanding of the other enables you to understand yourself, and the understanding of yourself enables you to understand God in yourself and choose whether and how you will serve that temple.

\section{Instead of a conclusion}

This possible consideration and understanding of St. Clement's ethics is not only due to the need to change the way the life of saints is understood, regardless of their beatifier, but to the understanding of the need for them. That means that what is always forgotten when speaking or discussing intercultural and interreligious dialogue is the fact that saints are not burdened with the need to satisfy the urges, desires and demands of those who currently rule, but the freedom of others. They order their own freedom by offering them knowledge and understanding of the universal values of love, peace .... the fundamental words through which it is argumented in the name of

\footnotetext{
${ }^{7}$ This gives Temkov the right to claim that "St. Clement is not only a magnificent moralist, but al-
} so our (Macedonian) model. He is the first and best ethicist in our culture." (Темков, 2006) 
God. Although, unfortunately, not so rarely, nowadays we are witnessing the violent deification of man!

All this is in fact because, regardless of how we name God, one is completely certain that God is ethics, not just a set of norms and obligations, but a need not to be excluded from the world and humanity. That is why it is no longer about what we will ask from God, but about what we will do for everyone to be in God's mercy.

To conclude this brief scheme of possible understanding of St. Clement's ethics, we also need to remember that only with this attitude toward ourselves, for ourselves and in relation to others and for others, to God, for God and on behalf of God, we can come to the answer of the question that is the reason for this text: whether in this world we are given by God's mercy so that someone can write us rules of the game or we are here to find God in ourselves, to show the others the possible way, to get to God together, to tell him thank you for teaching us how to think of what we inherit and leave, and act appropriately to it, denying ourselves from part of our commodity?

Unfortunately, the absence or lack of such an understanding of ethics, and in particular the interdisciplinary approach, especially in these regions that cannot complain of missing bloodshed in the name of God, unfortunately once again brings us to a situation only now, or more precisely, from the beginning, in which we discover our common roots as human, ethical beings, as God's creations, but more as God's providence and purpose, which by diversity creates common values for the world according to God's measure of man. 


\section{References}

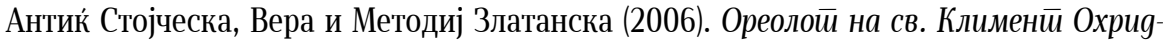
ски. Охрид. [s.n.]

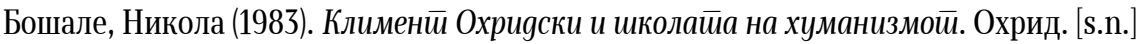

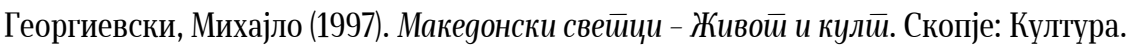

Каровски, Лазо и други (ур.) (1966). Клименӣ Охрияски. Битола: Матична библиотека „Климент Охридски“.

Климент Охридски (1996). Похвали и ӣоуки. Скопје: Табернакул.

Климент Охридски (1974). Жийија, слова и йоуки. Скопје: Македонска книга.

Конески, Блаже, Харалампие Поленаковиќ, Александар Спасов, Рада Угриновска (прир.) (1966). Книіа за Клименӣ Охрияски. Скопје: Кочо Рацин.

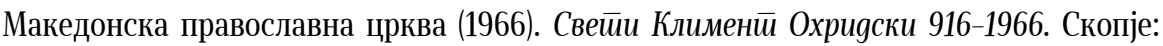
Синод на МПЦ.

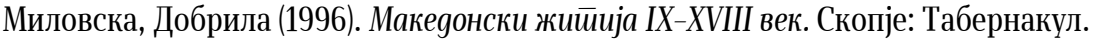

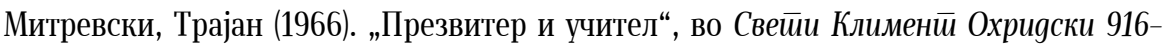
1966. Скопје: Синот на МПЦ, стр. 22-31.

Nurigiani, Giorgio (1972). The Macedonian genius through the centuries. London: David Harvey Publishers.

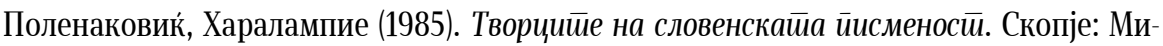
сла.

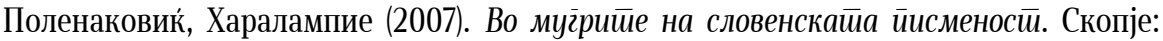
Култура.

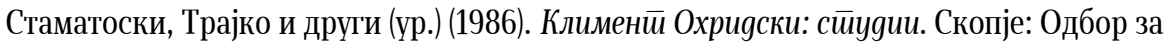
одбележување на 1.100-годишнината од доаѓњњето на Климент во Охрид и формирањето на Охридската школа за словенска култура и писменост.

Темков, Кирил (2003). „Свети Климент Охридски - Тргај се од злото и прави добро“.

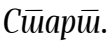

Темков, Кирил (2006). „Етичките погледи на свети Климент Охридски “. Преgавање

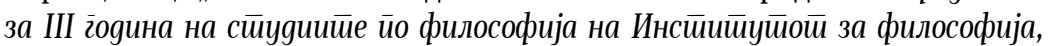

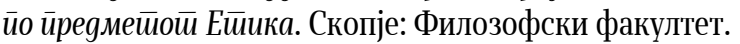

